\title{
BIOSCREENING OF THE METHANOLIC CRUDE EXTRACT OF ULVA LACTUCA AND ITS WATER FRACTION
}

\author{
Ahmed M. El-Ansary ${ }^{1 *}$, Doaa A. Ghareeb², Shaden M. Hanafy ${ }^{1}$ \\ ${ }^{1}$ Molecular Biology Department, GEBRI, University of Sadat City \\ ${ }^{2}$ Biochemistry Department, Faculty of Science, Alexandria University \\ *Corresponding author: Dr_alansary1@yahoo.com
}

\begin{abstract}
Marine algae have been use as a novel food with potential nutritional benefits, and in industry and medicine for various purposes. Recently, aquatic habitats have increasing been shown to provide a rich source of natural bioactive compounds. Green algae Ulva lactuca is a widespread macro algae occurring at all levels of the intertidal zone, in calm and protected harbours as deep as 10 meters and in northern climates. Many of its nutrients include iron, protein (15\%), iodine, vitamins (A, B1, and C) and trace elements. The present study investigated the bioactivity of Ulva lactuca methanolic crude extract and its water fraction. Also we identified on their different bioactive constituents using high performance liquid chromatography technique. Our results showed that methanolic crude extract of Ulva lactuca and its water fraction had phenolic and flavonoid active constituents acting in synergism to increase their bioactivity such as antioxidant, antiinflamatory and antihemolytic activities. Through 15 days, there was no mortality detected among mice injected with Ulva water fraction different doses. Therefore, we could not calculate the LD50 and accounted it as safe agent. Finally we concluded that Ulva water fraction safe to be used in the treatment of oxidative stress and inflammation related disorders.
\end{abstract}

Keywords: green algae Ulva lactuca, Ulva water fraction.

\section{INTRODUCTION}

Marine algae have been use as a novel food with potential nutritional benefits, and in industry and medicine for various purposes (Santoso et al., 2004). Recently, aquatic habitats have increasing been shown to provide a rich source of natural bioactive compounds with hypocholesterolemia, antiinflamatory, antiviral, antineoplastic, antimicrobial and hypertensive properties. According to their chemical structure most of isolated compounds belong to sulfated polysaccharides, phenolics, terpenoids, lactons, sterol and fatty acids (McDermid and Stuercke, 2003; Qi et al.,2006 and Duan et al., 2006). On the other hand, the antioxidant activity is one of the most important active in marine bioactive substances and lots of algal and algae-derived compounds exhibited potent antioxidant such as carotenoids, phenolics, terpenoids and sulphated polysaccharides. The antioxidant activity of these compounds are mainly attributed to scavenging activity against free radicals such as superoxide and hydroxyl radicals, chelating ability, quenching singlet and triplet oxygen, and reducing power (Ruberto et al., 2001and Athukorala et al., 2006).

Natural antioxidant such as $\alpha$-tocopherol, phenols and $b$-carotene found in higher plants are being use in the food industry to inhibit lipid peroxidation and they can protect the human body from free radicals and retard the progress of many chronic diseases (Matsukawa et al., 1997 and Qi et al., 2005). However, Gey, (1990) have reported that the synergistic action of wide spectrum of antioxidant is better than the activity of a single antioxidant, and that antioxidants from 
natural source (primarily foods) have a higher bioavailability and therefore higher protective efficacy against oxidative stress than synthetic antioxidants.

ROS and free radical capable of causing damage to biomolecules, such as nucleic acids, lipids, proteins and other cellular constituents (Kubo et al., 1992 and Halliwell 1996). The degradation and/ or modification of these molecules have been associated with various chronic diseases, such as cancer, coronary heart disease atherosclerosis, cataracts, ageing muscular dystrophy and some neurological disorders (Finkel and Holbrook, 2000; Cooke et al., 2002). For these reasons, many products with antioxidant properties are widely used in order to minimize oxidative damage to living cells and to prevent oxidative deterioration of food. Synthetic antioxidants such as butylated hydroxyanisol (BHA) and butylated hydroxyl toluene (BHT) are commonly used to inhibit lipid peroxidation (Farag et al., 1989). Now a day, BHT and BHA need to replaced with natural antioxidant, however they were found to be toxic, responsible for liver damage, promoters of carcinogenesis and alteration the enzyme activities, as well as general consumer rejection of synthetic food additives (Gulcin et al., 2002). Thus, it is important to develop, identify and utilized of new source of safe and effective antioxidants of natural origin (Li et al., 2007; Qi et al., 2005). Tumor Necrosis Factor Alpha (TNF- $\alpha$ ), is a proinflammatory cytokine produced by monocytes/macrophages and activated by mast cells, endothelial cells, fibroblasts, neurons and glial cells during acute inflammation and it is responsible for a wide range of cell signals about cell viability, gene expression, homeostasis control and synaptic integrity (Black et al., 1997).

TNF- $\alpha$ was described for the first time by Carswell et al. in 1975 as a protein component of serum of mice stimulated with bacterial antigens, and was brought to light the ability to induce death in cancer cell lines in vitro and in vivo to destroy transplanted sarcomas.
Characteristically, this cytokine was able to cause tumour cells death without compromising the viability of healthy cells. The subsequent isolation and molecular characterization of the gene have provided information on the structure and functioning of this molecule (Cereda et al., 2012).

The aim of this study was to analyze the crude methanolic extract obtained from Ulva lactuca and its different fractions using HPLC technique and evaluate their antioxidant, antiinflammatory and antihemolytic properties in vitro.

\section{MATERIALS AND METHODS}

\section{Algae selection and collection}

The green algae (Ulva lactuca) were collected from Abu Kir beach, Alexandria coast, identified and authenticated in Oceanography department, faculty of Science, Alexandria University.

Preparations of the methanolic crude extract and water fraction of green algae (Yacout et al., 2011)

The algae well washed with tap water then left to dry in air for two days. $500 \mathrm{~g}$ of dried algae were grinded, completely flooded with $1.5 \mathrm{~L}$ absolute methanol over night, and then filtrated. The filtrate was taken (methanolic extract) and algae were flooded again in absolute methanol over night then filtrated. The filtrates were collected and evaporated using rotary evaporator. The obtained methanolic extract was lyophilized (120 g). 110 grams of the dried extract were fractionated using distilled water $(0.5 \mathrm{~L} \times 2)$. The fraction was lyophilized and weighed $75 \mathrm{~g}$. The powder was collected and kept in refrigerator till used.

Quantitative determination of Ulva water fraction contents by high performance liquid chromatography (HPLC) (Qadir et al., 2009)

The analysis of water fraction of Ulva Lactuca extract was carried out on an Agilent-1100 HPLC system equipped with a quaternary gradient pump unit, ultra violet (UV) detector 
at a wave length of $320 \mathrm{~nm}$ and the analytical $406 \mathrm{~mm}, 5 \mu \mathrm{m}$ particle size) column (Agilent, Santa Clara, CA, USA) was used. Elution was carried out at a flow rate (retention time) of $0.075 \mathrm{ml} / \mathrm{min}$ at $23^{\circ} \mathrm{C}$. The mobile phase consisted of $8 \%$ acetonitrile, $22 \%$ isopropyl alchohol and $70 \%$ formic acid solution (1\%). All standards (Chlorogenic acid, Caffeic acid, 3,4-Dicaffeoyl quinic acid, 3,5-Dicaffeoyl quinic acid, 4,5-Dicaffeoylquinic acid, Gallic acid, Rutin, Tanic acid, Quercetin and Retinol) and sample were dissolved in distilled water (1 $\mathrm{mg} / \mathrm{ml}$ ) and were filtered through $0.22 \mu \mathrm{m}$ syringe filter prior to HPLC analysis. The injection volume was $20 \mu$ of either sample or standard. The results are calculated by internal normalization of the chromatographic peak area. Ulva water fraction identification was made by comparing the relative retention times of sample peaks with standards.

Determination of lethal dose 50 (LD $\left.{ }_{50}\right)$ of the water faction of the methanolic extract of Ulva Lactuca crude in mice (Oukkache et al., 2014)

25 healthy mice were divided into five groups, group one is control group subjected to free water intake. From group two to group five, mice were orally administered with the water fraction of the methanolic extract of Ulva lactuca at concentrations 10, 100, 500, $1000 \mathrm{mg} / \mathrm{kg}$ body weight for 15 days daily. Then mice were scarified and the blood sample for each mouse was collected in EDTA tubes to get plasma. Liver function tests, kidney function tests, cholesterol level, triglycerides level and TNF- $\alpha$ cytokine level were measured at plasma samples.

Determination of DPPH (2, 2-Diphenyl-1picryl hydrazyl) scavenging activity The assay was done according to (Blois, 1958) column was Zorbax Eclipse XDB-C18 (150 x

Determination of NO (Nitric oxide) radical scavenging activity

The assay was done according to (Garrat, 1964; Marcocci et al., 1994)

Cytoxicity study on Human Red Blood Corpuscles (HRBCs) membrane stabilizing

The assay was done according to (Oyedapo et al., 2010)

Routine blood analyses: Liver function tests, kidney function tests, cholesterol level and triglycerides level were measured using commercial kits.

Determination of TNF- $\alpha$ by enzyme linked immunosorbent assay (ELISA):Plasma TNF- $\alpha$ content was measured by using Duo set enzyme-linked immunoassay (ELISA) kits specific for rat TNF- $\alpha$ according to the manufacture's instructions (Bender, Vienna, Austria).

Semi-Quantitative analysis of TNF- $\alpha$ using reverse transcriptase polymerase chain reaction (PCR) technique

TNF- $\alpha$ RNA was isolated from white blood cells (WBCs) and the assay was done according to (Bustin, 2000); where TNF- $\alpha$ sense primer 5CAGACCCTCACACTCAGATCATCTT-3 and antisense primer 5CAGAGCAATGACTCCAAAGTAGACCT-3 $\quad(\sim 150$ bp product).

Experimental design and statistical analyses

All data expressed as the mean \pm standard deviation (SD). The differences were considered to be statistically significant at $p<$ 0.05 . Statistical analysis was performed using the unpaired Student's $t$-test and one-way analysis of variance (ANOVA) using primer of Biostatistics (Version 5) software program.

\section{RESULTS AND DISCUSSION}

Table 1: Bioscreening of different concentrations of Ulva lactuca crude extract and its fractions: 2, 2diphenyl-1-picryl hydrazyl (DPPH) radical savenging activity (antioxidant activity), nitric oxide (NO) radical savenging activity (antiinflamatory activity) and red blood cells (RBCs) detoxicity (antihemolytic 


\begin{tabular}{|c|c|c|c|c|}
\hline Fraction & $\begin{array}{c}\text { Concentration (mg } \\
\text { /ml) }\end{array}$ & $\begin{array}{c}\text { DPPH } \\
\text { scavenging } \\
\text { activity \% }\end{array}$ & $\begin{array}{c}\text { NO scavenging } \\
\text { activity \% }\end{array}$ & $\begin{array}{c}\text { Antihemolytic } \\
\text { effect \% }\end{array}$ \\
\hline \multirow{2}{*}{ Crude extract } & $\mathbf{1}$ & 12.357 & 6.548 & 0.001 \\
\cline { 2 - 5 } & $\mathbf{2}$ & 60.214 & 33.033 & 19.002 \\
\hline \multirow{2}{*}{ Water fraction } & $\mathbf{1}$ & 34.096 & 26.871 & 0.1 \\
\cline { 2 - 5 } & $\mathbf{2}$ & 43.992 & 37.744 & 14.795 \\
\hline
\end{tabular}

Table 2: HPLC data for Ulva lactuca extract

\begin{tabular}{|c|c|c|}
\hline Test & Crude extract & $\begin{array}{c}\text { Water fraction of the crude } \\
\text { extract }\end{array}$ \\
\hline Chlorogenic acid $(\mathbf{m g} / \mathbf{l})$ & 64.355 & $5.93 \mathrm{e}-1$ \\
\hline Caffeic acid $(\mathbf{m g} / \mathbf{l})$ & 50.52 & $3.86 \mathrm{e}-1$ \\
\hline 3,4-Dicaffeoyl quinic acid $\mathbf{( m g / l )}$ & 34.75 & $\mathrm{ND}$ \\
\hline 3,5-Dicaffeoyl quinic acid $(\mathbf{m g} / \mathbf{l})$ & 110.12 & 1.064 \\
\hline 4,5-Dicaffeoylquinic acid $(\mathbf{m g} / \mathbf{l})$ & 42.922 & 1.299 \\
\hline Gallic acid $(\mathbf{m g} / \mathbf{m l})$ & 13.354 & $\mathrm{ND}$ \\
\hline Rutin $(\mathbf{m g} / \mathbf{l})$ & 3.557 & $\mathrm{ND}$ \\
\hline Tanic acid $(\mathbf{m g} / \mathbf{m l})$ & 4.63 & $9.25 \mathrm{e}-3$ \\
\hline Quercetin $(\mathbf{m g} / \mathbf{l})$ & 1.1 & 315.84 \\
\hline Retinol $(\boldsymbol{\mu g} / \mathbf{l})$ & 258.623 & \\
\hline
\end{tabular}

Table 3: Effect of the orally administration of different Ulva water fraction doses on liver function parameters in mice sera of different experimental animal groups

\begin{tabular}{|c|c|c|c|c|}
\hline Groups / Tests & AST & ALT & Total Protein & Albumin \\
\hline Control & $8.612 \pm 0.583$ & $29.98 \pm 1.361$ & $5.102 \pm 0.346$ & $1.105 \pm 0.017$ \\
\hline $\mathbf{1 0} \mathbf{m g} / \mathbf{k g}$ & $7.89 \pm 0.907$ & $29.45 \pm 4.477$ & $10.44 \pm 0.473^{*}$ & $0.825 \pm 0.092^{*}$ \\
\hline $\mathbf{1 0 0} \mathbf{m g} / \mathbf{k g}$ & $8.536 \pm 0.52$ & $22.03 \pm 3.875^{*}$ & $12.35 \pm 0.625^{*}$ & $1.024 \pm 0.177$ \\
\hline $\mathbf{5 0 0} \mathbf{m g} / \mathbf{k g}$ & $8.044 \pm 0.515$ & $28.7 \pm 1.65$ & $10.73 \pm 0.253^{*}$ & $0.838 \pm 0.097^{*}$ \\
\hline $\mathbf{1 0 0 0} \mathbf{m g} / \mathbf{k g}$ & $8.104 \pm 0.63$ & $25.16 \pm 3.937$ & $10.7 \pm 0.6^{*}$ & $0.984 \pm 0.189$ \\
\hline
\end{tabular}

Table 4: Effect of the orally administration of different Ulva water fraction doses on kidney function parameters in mice sera of different experimental animal groups

\begin{tabular}{|c|c|c|c|}
\hline Groups / Tests & Urea & Creatinine & Uric Acid \\
\hline Control & $81 \pm 9.263$ & $0.633 \pm 0.082$ & $6.124 \pm 0.096$ \\
\hline $10 \mathrm{mg} / \mathrm{kg}$ & $81.11 \pm 7.842$ & $0.717 \pm 0.041$ & $6.005 \pm 0.12$ \\
\hline $100 \mathrm{mg} / \mathrm{kg}$ & $65.85 \pm 4.26 *$ & $0.717 \pm 0.117$ & $5.98 \pm 0.143$ \\
\hline $500 \mathrm{mg} / \mathrm{kg}$ & $55.7 \pm 6.455^{*}$ & $0.862 \pm 0.133 *$ & $6.225 \pm 0.262$ \\
\hline $1000 \mathrm{mg} / \mathrm{kg}$ & $56.34 \pm 7.991^{*}$ & $0.9 \pm 0.089 *$ & $6.106 \pm 0.526$ \\
\hline
\end{tabular}


Table 5: Effect of the orally administration of different Ulva water fraction doses on lipids level in mice sera of different experimental animal groups

\begin{tabular}{|c|c|c|}
\hline Groups / Tests & Total Cholesterol & Triglycerides \\
\hline Control & $75.83 \pm 3.898$ & $310.4 \pm 3.289$ \\
\hline $\mathbf{1 0} \mathbf{m g} / \mathbf{k g}$ & $76.46 \pm 5.632$ & $305.1 \pm 5.567$ \\
\hline $\mathbf{1 0 0} \mathbf{m g} / \mathbf{k g}$ & $78.12 \pm 1.576$ & $312.1 \pm 10.87$ \\
\hline $\mathbf{5 0 0} \mathbf{m g} / \mathbf{k g}$ & $83.4 \pm 3.627^{*}$ & $317 \pm 12.7$ \\
\hline $\mathbf{1 0 0 0} \mathbf{m g} / \mathbf{k g}$ & $81.6 \pm 4.341$ & $366.1 \pm 46.35^{*}$ \\
\hline & & \\
\hline
\end{tabular}

Table 6: Tumor necrosis factor (TNF- $\alpha$ ) level and gene expression fold

\begin{tabular}{|c|c|c|}
\hline Groups / Tests & TNF- $\alpha \mathbf{~} \mathbf{p g} / \mathbf{m l})$ & TNF- $\alpha$ gene expression fold \\
\hline Control & $12830.8 \pm 104.301$ & $1.142 \pm 0.009$ \\
\hline $\mathbf{1 0 m g / k g}$ & $11201 \pm 202.416^{*}$ & $1.121 \pm 0.003^{*}$ \\
\hline $\mathbf{1 0 0} \mathbf{m g} / \mathbf{k g}$ & $9201 \pm 164.256^{*}$ & $0.922 \pm 0.004^{*}$ \\
\hline $\mathbf{5 0 0} \mathbf{m g} / \mathbf{k g}$ & $9000 \pm 180.412^{*}$ & $0.91 \pm 0.001^{*}$ \\
\hline $\mathbf{1 0 0 0} \mathbf{m g} / \mathbf{k g}$ & $13830.8 \pm 150.341^{*}$ & $1.2 \pm 0.005^{*}$ \\
\hline & & \\
\hline
\end{tabular}

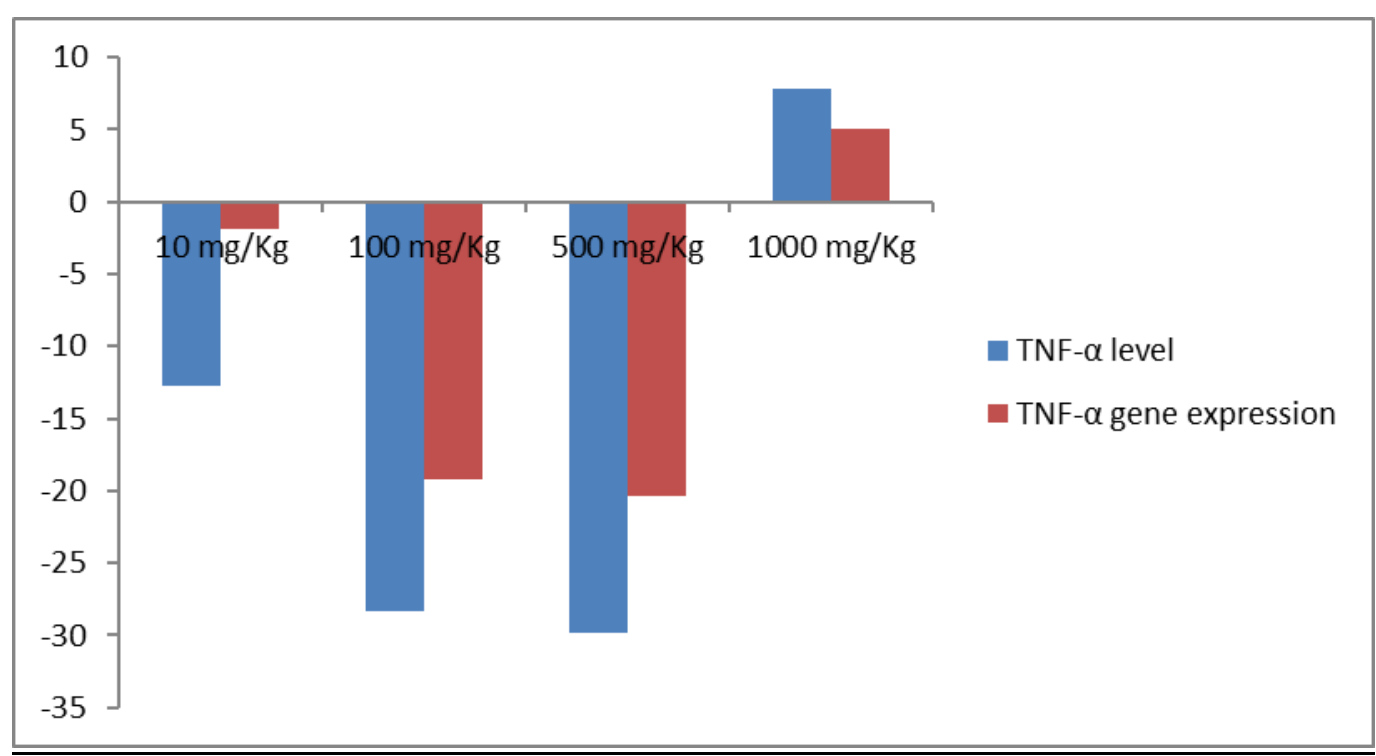

Fig. 1: The percent of increasing or decreasing of TNF- $\alpha$ level and gene expression in different treated groups 


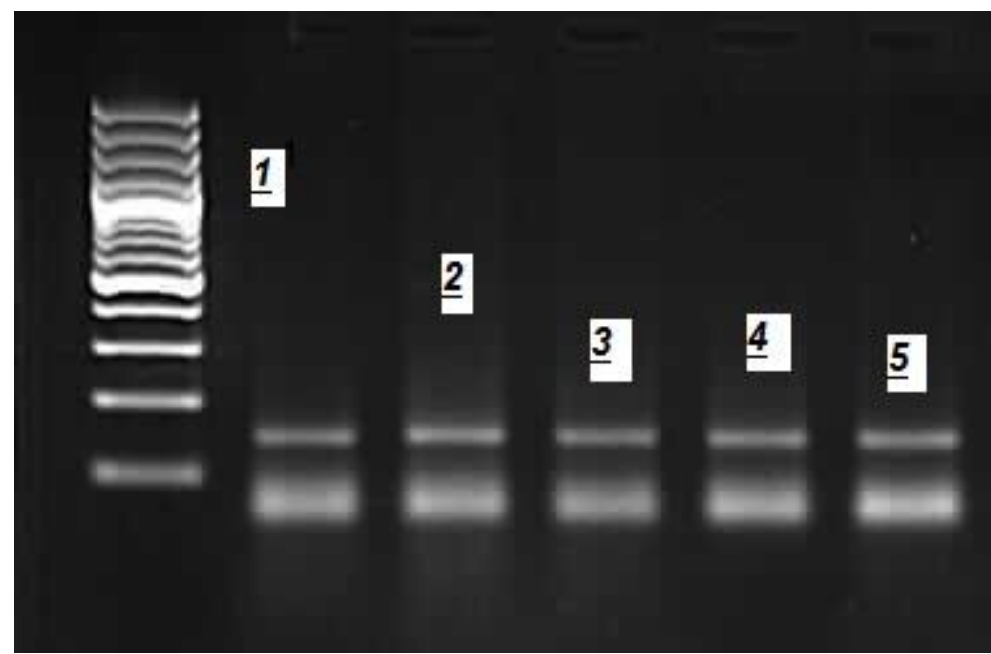

Fig. 2: TNF- $\alpha$ gene expression in different treated groups. $1^{\text {st }}$ lane was the DNA ladder, lane no. 1 was control group, lane no. $\underline{2}$ was $10 \mathrm{mg} / \mathrm{kg}$ group, lane no. $\underline{3}$ was $100 \mathrm{mg} / \mathrm{kg}$ group, lane no. $\underline{4}$ was $500 \mathrm{mg} / \mathrm{kg}$ group and lane no. $\underline{5}$ was $1000 \mathrm{mg} / \mathrm{kg}$ group

We investigated the bioscreening activities for the water fraction of the methanolic Ulva lactuca extract, and our results provide that crude extract and its fractions had antioxidants, anti-inflammatory and anti hemolytic activities. These effects were concentration dependent where $2 \mathrm{mg} / \mathrm{ml}$ of each one showed the more potent activity. For DPPH scavenging activity, the most powerful one was crude extract followed by water fraction (Table 1). While for NO scavenging activity, butanol was the most potent fraction followed by water one (Table 1). Finally for antihemolytic activity, crude extract was the most effective one followed by water fraction one (Table 1). Overall among tested fractions, water one was the most effective therefore it was chosen as a candidate for in vivo study. Since Ulva water fraction showed these amazing activities the next step was the determination of safe dose and the possible toxicity.

In $L D_{50}$ test, there was no mortality detected among mice through 15 days of injection with Ulva water fraction at different doses (10$1000 \mathrm{mg} / \mathrm{kg}$ ). Therefore, we could not calculate the $\mathrm{LD}_{50}$ and accounted it as safe agent as shown in tables 3,4 and 5 . But at dose $500 \mathrm{mg} / \mathrm{kg}$ and $1000 \mathrm{mg} / \mathrm{kg}$ it was noticed that the total protein concentration (table 3) was dramatically increased which associated with decreased albumin level that could be due to formation of new protein like globulin (inflammatory protein) due to hepatitis as Thapa and Walia (2007) mentioned. Also urea level (table 4) significantly decreased compared to control due to impairment in urea cycle caused by hepatocyte inflammation. Also creatinine level (table 4) significantly increased compared to control which means that renal injury began to occur by increasing the dose. Also increasing Ulva water fraction dose accompanied by hypercholesterolemia and high triglycerides level (table 5). All together the chosen safe dose was $100 \mathrm{mg} / \mathrm{Kg}$ body weight.

It was clearly noticed that Ulva water fraction had therapeutic antioxidant and antiinflammatory effects since HPLC analysis revealed the presence of phenolic and flavonoid active constituents in high content e.g. gallic acid, quercetin and retinol (table 2) acting in synergism to increase its bioactivity such as antioxidant and antiinflammatory activities. Cook and Samman (1996), Aneta et al., (2007) and Lui et al., (2010) reported that phenolic and flavonoid compounds have high antioxidant and antiinflammatory capacities.

Also Ulva water fraction lightened the inflammation through decreasing the 
proinflamatory cytokine TNF- $\alpha$ level and down regulation of its gene (table 6 and figure 1 and 2).

The results of this study suggest that Ulva lactuca and its water fraction had phenolic and flavonoid active constituents offered a potential use as antioxidant and antiinflammatory candidate to prevent the progression of many disorders. However, further detailed investigations are needed to isolate the phytoconstituents responsible for their and antiinflammatory actions.

\section{REFERENCES}

Aneta, W.; Oszmianski, J. and Czemerys, R. (2007). Antioxidant activity and phenolic compounds in 32 selected herbs. Food Chemistry, 105:940-949.

Athukorala, Y.; Nam, K. and Jeon, Y. (2006). Antiproliferative and antioxidant properties of an enzymatic hydrolysate from brown alga Ecklonia cava. Food Chem. Toxicol., 44:1065-1074.

Black, R.A.; Rauch, C.T.; Kozlosky, C.J.; Peschon, J.J.; Slack, J.L. and Wolfson, M.F. (1997). A metalloproteinase disintegrin that releases tumournecrosis factor-alpha from cells. Nature, 385:729-733.

Blois, M. S. (1958). Antioxidant determinations by the use of a stable free radical. Nature, 29:1199 -1200.

Bustin, S.A. (2000). Absolute quantification of mRNA using real-time reverse transcription polymerase chain reaction assays. Journal of Molecular Endocrinology, 25:169-193.

Cook, N. C. and Samman, S. J. (1996). Flavonoids-Chemistry, Metabolism, Cardioprotective Effects and Dietary Sources. Nutr. Biochem., 7:66-76.

Cooke, M. S.; Evans, M. D.; Mistry, N. and Lunec, J. (2002). Role of dietary antioxidants in the prevention of in vivo oxidative DNA damage. Nut. Res. Rev., 15:19-41.

Carswell, E.A.; Old, L.J.; Kassel, R.L.; Green, S.; Fiore, N. and Williamson, B. (1975). An endotoxininduced serum factor that causes necrosis of tumors. Proc Natl Acad Sci USA, 72:66-70.

Cereda, C.; Gagliardi, S.; Cova, E.; Diamanti L. and Ceroni M. (2012). The Role of TNF
Alpha in ALS: New Hypotheses for Future Therapeutic Approaches. In Tech, 18:413-436.

Duan, X. J.; Zhang, W. W.; Li, X. M. and Wang, B. G. (2006). Evaluation of antioxidant property of extract and fractions obtained from a red alga, Polysiphonia urceolata. Food Chem., 95:37-43.

Farag, R. S.; Badei, A. Z. M.; Hewadi, F.M. and EL-Baroty, G. S. (1989). Antioxidant activity of some spice essential oils on linoleic acid oxidation in aqueous media. Am. Oil. Chem. Soc., 66: 792799.

Finkel, T. and Holbrook, N. J. (2000). Oxidants, oxidative stress and the biology of ageing. Nature, 408:239-247.

Garrat, D. C. (1964). The Quantitative analysis of Drugs. Chapman and Hall Ltd., Japan, 3:456- 458 .

Gey, K. F. (1990). The antioxidant hypothesis of cardiovascular disease: epidemiology and mechanisms. Biochem. Soc. Transactions, 18:10411045.

Gulcin, I.; Oktay, M; Kufrevioeglu, O. and Aslan A. (2002). Determination of antioxidant activity of lichen cetraria islandica (L). Ach. J. Ethnopharmacol., 79: 325-329.

Halliwell, B. (1996). Oxidative stress, nutrition and health. Experimental strategies for optimization of nutritional antioxidant intake in humans. Free Radical Res., 25:57-74.

Kubo, I.; Himejma, M.; Tsujimoto, K.; Muroi, H. and Ichikawa, N. (1992). Antibacterial activity of crinito and its potentiation. J. Nat. Prod., 55:780-785.

Li, A. H.; Cheng, K.; Wong, C.; King-Wai, F.; Feng, C. and Yue, J. (2007). Evaluation of antioxidant capacity and total phenolic content of different fractions of selected microalgae. Food Chem., 102: 771-776.

Liu, C.; Wang, J.; Zhou, S.; Wang, B. and Ma, X. (2010). Association between -238 but not -308 polymorphism of Tumor necrosis factor alpha (TNF-alpha)v and unexplained recurrent spontaneous abortion (URSA) in Chinese population. Reprod Biol Endocrinol., 8:114.

Marcocci, L.; Packer, L.; Droy-Lefaix, M. T. (1994). Antioxidant action of Ginkgo biloba extracts EGB 761. Methods Enzymol, 234: 462-475.

Matsukawa, R..; Dubinsky, Z.; Kishimoto, E.; Masaki, K.; Masuda, Y.; Takeuchi, T.; 
Chihara, M.; Yamamoto, Y.; Niki, E. and Karube, I. (1997). A comparison of screening methods for antioxidant activity in seaweeds. Appl. Phycol., 9:29-35.

McDermid, K. J. and Stuercke, B. (2003). Nutritional composition of edible Hawaiian seaweeds. J. Appl. Phycol., 15:513-524.

Oukkache, N.; El Jaoudi, R.; Ghalim, N.; Chgoury, F.; Bouhaouala, B.; El Mdaghri, N. and Sabatier, J. (2014). Evaluation of the Lethal Potency of Scorpion and Snake Venoms and Comparison between Intraperitoneal and Intravenous Injection Routes. Toxins, 6:1873-1881.

Oyedapo, O. O.; Akinpelu, B. A.; Akinwunmi, K. F.; Adeyinka M. O. and Sipeolu, F. O. (2010). Red blood cell membrane stabilizing potentials of extracts of Lantana camara and its fractionsint. J. Plant Physiol. Biochem., 2(4):46-51.

Qadir, S.; Kwon, M.; Han, J.; Ha, J.; Chung, H.; Ahn, J. and Lee, H. (2009). Effect of different extraction protocols on anticancer and antioxidant activities of Berberis koreana bark extracts. J. Biosci. Bioeng., 107:331-339.

Qi, H.; Zhang, Q.; Zhao, T., Hu, R.; Zhangc, K., and $\mathrm{Li}, \mathrm{Z}$. (2006). In vitro antioxidant activity of acetylated and benzoylated derivatives of polysaccharide extracted from Ulva pertusa (Chlorophyta). Bioorganic Med. Chem. Let., 24412445.

Qi, H.; Zhao, T.; Zhang, Q.; Li, Z.; Zhao, Z. and Xing, R. (2005). Antioxidant activity of different molecular weight sulfated polysaccharides from Ulva pertusa Kjellm (Chlorophyta). Appl. Phycol., 17:527-534.

Ruberto, G.; Baratta, M. T.; Biondi, D. M. and Amico, V. (2001). Antioxidant activity of extracts of the marine algal genus Cystoseira in a micellar model system. J. Appli. Phycol., 13:403-407.

Santoso, J.; Yumiko, Y.; and Takeshi, S. (2004). Antioxidant activity of methanol extracts from Indonesian seaweeds in an oil emulsion model. Fish Sci., 70:183-188.

Thapa, B. R. and Walia, A. (2007). Liver Function Tests and their Interpretation. Indian J Pediatr, 74(7):663-671.

Yacout, G.; Ghareeb, D. A.; Elguindy, N. M. and Abd Elmoneam, A. A. (2011) Phytochmical constituents and bioscreening activities of Alexandria Mediterranean Sea green and red algae. FPSB. 5(SI 1):79-82. 